\title{
PENANGANAN LIMBAH MEDIS DAN PERILAKU PETUGAS CLEANING SERVICE DI RSUD Dr. SOETOMO SURABAYA TAHUN 2016
}

\author{
Risca Anesea, Erna Triastuti , Ferry Kriswandana
}

\begin{abstract}
Health workers who handle medical waste are at risk of the diseases faced because of germs from the skin infections, anthrax, meningitis, dengue, hepatitis $A$, Hepatitis $B$ and $C$. The bacteria present in the blood are transmitted through blood. The highest risk of being infected by these diseases is when impaled by sharp or pointed object of the waste because it can damage the skin. The purpose of this study was to determine the behavior of CS officers (Cleaning Service) and the handling of medical waste in Dr. Soetomo hospital.

This is a descriptive research with cross sectional approach. The collection of data was carried out through observation and interviews. The sample was 75 CS officers. Data were analyzed descriptively with table analysis.

The results showed that Cleaning Services' level of knowledge at Dr. Soetomo Hospital on handling medical waste with "Good" criteria was $90.8 \%$. The CS attitude with "good" criteria was $88 \%$ and poor was $5.3 \%$. CS's behavior with "Good" criteria was 92\% and "poor" was 6.7\%.

It can be concluded that of 75 Cleaning Service at Hospital Dr. Soetomo, most of them were well behaved and only a small proportion have poor behavior. The handling of medical waste in Dr. Soetomo hospital has been qualified in accordance with Kepmenkes No 1204 of 2004. It is recommended to conduct counseling on the importance of the use of personal protective equipment and the dangers of medical waste. Warning is also needed to officers whose work is not according to the rules.
\end{abstract}

Keywords: CS Behavior, handling of medical waste

\section{PENDAHULUAN}

Rumah sakit merupakan penghasil limbah klinis terbesar. Berbagai jenis limbah yang dihasilkan di rumah sakit dan unit- unit pelayanan kesehatan bisa membahayakan dan menimbulkan gangguan kesehatan bagi pengunjung dan terutama kepada petugas yang menangani limbah tersebut serta masyarakat sekitar rumah sakit.(Depkes, RI 1995)

Petugas yang menangani limbah medis mempunyai risiko terhadap penyakit AIDS(Acquired Immune Deficiency Syndrome), Infeksi kulit, Antraks, Meningitis, Demam berdarah, Septikimia, Bakteriemia, Kandademia, Hepatitis A, Hepatitis B dan $\mathrm{C}$ yang terdapat di dalam limbah medis. Kuman. Risiko tertular penyakit ini paling besar terjadi apabila orang tertusuk benda limbah yang tajam atau runcing karena benda itu dapat merusak kulit. Lewat luka itu virus dan kuman lainya masuk ke dalam tubuh. (Fransisca,2013, hal 2)

Dari pernyataan tersebut maka perilaku sangat berpengaruh terhadap petugas dalam menangani limbah medis agar tidak terjadi penularan penyakit. Adapun perilaku kesehatan adalah suatu respons seseorang atau organisme terhadap stimulus atau obyek yang berkaitan dengan sakit dan penyakit, sistem pelayanan kesehatan, makanan dan minuman, serta lingkungan. (Notoatmojo, 2012)

RSUD Dr. Soetomo merupakan Rumah sakit tipe A yang terletak di Jalan Mayjen Prof. Dr. Moestopo 6 - 8 Surabaya. Jumlah tempat tidur sebanyak 1493 buah yang terbagi di Irna Medik,
Irna Bedah, Irna Anak, Irna Obgyn, Irna Jiwa, IRD( Instalasi Rawat Darurat), GBPT( Gedung Bedah Pusat Terpadu) dan GRIU (Gedung Rawat Inap Utama). BOR( pemanfaatan tempat tidur) $75 \%$. Sebagai rumah sakit pusat rujukan Indonesia bagian Timur dan rumah sakit pendidikan tentu saja banyak aktivitas yang dilakukan sehingga akan menghasilkan limbah dalam jumlah yang besar. Berdasarkan data yang diperoleh dari Instalasi Sanitasi Lingkungan jumlah timbulan sampah ratarata selama bulan Januari- Juni 2016 sebanyak 43.600 ton/ bulan. Diperkirakan dalam sehari kurang lebih sekitar 1400 ton limbah medis yang dihasilkan.

Dari observasi awal di RSUD Dr. Soetomo Surabaya ditemukan beberapa masalah dalam pengelolaan limbah medis yaitu masih ada petugas yang tidak menggunakan APD (Alat Pelindung Diri) pada saat pemilahan maupun pengangkutan karena merasa terganggu apabila menggunakan masker atau sarang tangan, persediaan APD diruangan terbatas, sampah medis masih tercampur dengan sampah nonmedis, serta adanya sampah yang tidak segera diangkut sehingga melebihi kapasitasnya, selain daripada itu juga ditemukan petugas yang tertusuk jarum suntik saat melakukan penanganan limbah benda tajam karena tidak menggunakan sarung tangan.

Penelitian ini menggunakan metode penelitian deskriptif dengan maksud untuk menggambarkan perilaku petugas CS dalam penanganan limbah medis di RSUD Dr. Soetomo Surabaya dan menurut waktunya termasuk penelitian cross sectional. 
Populasi yang digunakan dalam penelitian ini adalah petugas CS yang bertugas di ruangan yang menghasilkan limbah medis dan petugas pengangkut sampah yang keseluruhan berjumlah 290 orang.

Besar sampel yang diambil, dengan menggunakan rumus slovin sebagai berikut( Riduwan, 2005):

$$
\begin{aligned}
& \mathrm{n}=\frac{N}{1+N e^{2}} \\
& \text { keterangan : } \\
& \mathrm{n}=\text { besar sampel } \\
& \mathrm{N}=\text { besar populasi } \\
& \mathrm{e}=\text { batas toleransi kesalahan }(0,1)
\end{aligned}
$$

Maka besar sampel yang diperoleh adalah :

$$
\mathrm{n}=\frac{290}{1+290\left(0,0^{2}\right)}
$$

$$
\begin{aligned}
& =\frac{290}{1+25} \\
& =\frac{290}{3.9}=74,36
\end{aligned}
$$

dibulatkan menjadi 75 orang.

Pengambilan sampel dilakukan secara proporsional random sampling untuk menentukan besar sampel pada tiap- tiap unit pelayanan kesehatan dengan menggunakan rumus sebagai berikut(Riduwan, 2010) :

$$
n i=\frac{N i}{N} x n
$$

Keterangan:

ni =besar sampel untuk area ke $\mathrm{i}$

$\mathrm{Ni}=$ besar sub populasi untuk area ke $\mathrm{i}$

$\mathrm{N}=$ besar populasi

$\mathrm{n}=$ besar sampel

Tabel 1

\begin{tabular}{|c|c|c|c|}
\hline No & Kelompok Umur & Frekuensi & Presentase (\%) \\
\hline 1 & $15-25$ & 7 & 9,3 \\
\hline 2 & $21-25$ & 14 & 18,7 \\
\hline 3 & $26-30$ & 8 & 24 \\
\hline 4 & -35 & 5 & 20 \\
\hline 5 & $36-40$ & 8 & 10,7 \\
\hline 6 & $>40$ & 13 & 17,3 \\
\hline & Total & 75 & 100 \\
\hline $\begin{array}{l}\text { Petu } \\
25 \\
\text { beru } \\
\text { beru } \\
\text { beru } \\
\text { beru }\end{array}$ & $\begin{array}{l}\text { rdasarkan tabel } 2 \text { bahwa dari } 75 \\
\text { di RSUD Dr. Soetomo yang berumur } 15- \\
\text { sebanyak } 7 \text { petugas }(9,3 \%) \text {, yang } \\
-25 \text { sebanyak } 14 \text { petugas }(18,7 \%) \text {, yang } \\
-30 \text { sebanyak } 18 \text { petugas }(24 \%) \text {, yang } \\
-35 \text { sebanyak } 15 \text { petugas }(20 \%) \text {, yang } \\
36-40 \text { sebanyak } 8 \text { petugas }(10,7 \%)\end{array}$ & \multicolumn{2}{|c|}{$\begin{array}{l}\text { sebanyak } 13 \text { petugas(17,3\%). Berdasarkan umur } \\
\text { tersebut termasuk dalam usia produktif. Pada usia } \\
\text { produktif manusia akan memiliki semangat kerja, } \\
\text { idealisme, inteligensi tinggi, mentalitas yang baik } \\
\text { dan kemauan untuk bekerjasepenuhnya } \\
\text { mengerjakan apa yang menjadi tanggung jawabnya } \\
\text { (Handoko, 1995). }\end{array}$} \\
\hline
\end{tabular}

Besar Sampel Petugas Cleaning Service Tiap Ruang Pelayanan Kesehatan di RSUD Dr. Soetomo Surabaya Tahun 2016

\begin{tabular}{clll}
\hline No & Ruang & Jumlah & Sampel \\
& & 7 & 2 \\
\hline 1 & Jiwa & 42 & 10 \\
\hline 2 & GPDT & 33 & 9 \\
\hline 3 & IGD & 24 & 8 \\
\hline 4 & Irna Bedah & 32 & 8 \\
\hline 5 & Irna Medik & 31 & 6 \\
\hline 6 & IRJ & 22 & 12 \\
\hline 7 & Irna Anak & 46 & 3 \\
\hline 8 & GRIU & 10 & 7 \\
\hline 9 & Irna Obgyn & 28 & 3 \\
\hline 10 & GBPT & 11 & 1 \\
\hline 11 & Sampah Umum & 4 & 75 \\
\hline 12 & Sampah Medis & 290 & \\
\hline \multicolumn{7}{r}{} & & & \\
\hline
\end{tabular}

\section{HASIL DAN PEMBAHASAN}

Dari hasil penelitian yang dilakukan di RSUD Dr. Soetomo Surabaya didapatkan hasil sebagai berikut : Umur Petugas

Tabel 2

DISTRIBUSI PETUGAS CS BERDASARKAN UMUR 
Pengetahuan petugas

Tabel 3

DISTRIBUSI FREKUENSI PETUGAS CS BERDASARKAN TINGKAT PENGETAHUAN TENTANG PENANGANAN LIMBAH MEDIS DI RSUD DR. SOETOMO SURABAYA TAHUN 2016

\begin{tabular}{llll}
\hline No & Kriteria & Jumlah petugas & $\begin{array}{l}\text { Presentase } \\
(\%)\end{array}$ \\
\hline 1 & Baik & 68 & 90,67 \\
\hline 2 & Cukup & 7 & 9,33 \\
\hline 3 & Kurang & 0 & 0 \\
\hline Jumlah & & 75 & 100 \\
\hline
\end{tabular}

Berdasarkan tabel 3 diatas tingkat pengetahuan petugas CS di RSUD Dr. Soetomo tentang penanganan limbah medis dengan kriteria baik sebesar $(90,7 \%)$ dan sebesar 9,2 \% berpengetahuan cukup. Hal ini disebabkan sebagian besar sudah mengetahui tentang penanganan limbah medis karena sudah dilakukan pengarahan oleh pengawas CS setiap hari senin dan kamis. Pengetahuan bisa juga didapat dari pengalaman kerja karena sebagian besar petugas CS memiliki masa kerja yang sudah lama. Petugas dengan berpengetahuan cukup karena belum mengetahui bahwa sampah non medis yang tercampur dengan sampah non medis masuk dalam golongan sampah medis. Sehingga mereka tidak mengetahui bahwa bisa terjadi penularan penyakit melalui limbah medis. Petugas yang tidak mengetahui bahaya limbah medis akan menganggap remeh penggunaan APD karena tidak mengetahui bahaya penularan penyakit yang mereka hadapi. Sehingga perlu dilakukan oleh pihak sanitasi lingkungan tentang bahaya limbah medis dan pentingnya penggunaan APD. Petugas juga tidak mengetahui bahwa jalur pengangkutan makanan dan sampah medis harus dipisahkan karena dalam praktek sehari- hari tidak dibedakan antara jalur sampah medis dengan jalur makanan. Dikhawatirkan akan terjadi kontaminasi silang apabila jalur makanan dan sampah medis tidak dibedakan. Sebaiknya dari pihak rumah sakit membuat kebijakan untuk memisahkan jalur makanan dengan jalur pengangkutan sampah medis.

Menurut Sudiharti dan Solikhah (2011) pengetahuan terbentuk dengan dipengaruhi oleh beberapa faktor yang dapat digolongkan menjadi dua bagian yaitu faktor internal dan eksternal. Faktor internal antara lain yaitu umur dan intelegensi sedangkan faktor eksternal yaitu pendidikan, lingkungan, pengalaman, informasi, dan orang yang dianggap penting. Pendidikan sebagai faktor eksternal pembentuk pengetahuan dengan melihat hasil penelitian bahwa tingkat pengetahuan petugas CS dalam melakukan pembuangan sampah medis sebagian besar sudah baik karena mayoritas merupakan lulusan SMA. Semakin rendah pendidikan seseorang maka akan menghambat perkembangan sikap seseorang terhadap penerimaan, informasi dan nilai- nilai yang baru diperkenalkannya. Sebaliknya semakin tinggi pendidikan seseorang maka semakin mudah menerima informasi, dan pada akhirnya makin banyak pula pengetahuan yang dimilikinya. Faktor internal yang mempengaruhi pengetahuan yaitu umur, dimana seseorang semakin bertambah umurnya, maka akan berkurang daya penangkapan informasinya. Hal ini terbukti dalam penelitian ini bahwa responden dengan umur lebih dari 40 tahun jauh lebih sedikit. Hal ini menandakan bahwa faktor pembentuk pengetahuan baik internal maupun eksternal berpengaruh terhadap tingkat pengetahuan seseorang.

\section{Sikap Petugas}

Tabel 4

DISTRIBUSI FREKUENSI PETUGAS CS BERDASARKAN SIKAP TERHADAP PENANGANAN LIMBAH MEDIS DI RSUD DR. SOETOMO SURABAYA TAHUN 2016

\begin{tabular}{|c|c|c|c|}
\hline No & Kriteria & Jumlah petugas & Presentase(\%) \\
\hline 1 & Baik & 66 & 88,00 \\
\hline 2 & Cukup & 5 & 6,67 \\
\hline 3 & Kurang & 4 & 5,33 \\
\hline & Jumlah & 75 & 100 \\
\hline
\end{tabular}

Bedasarkan tabel 4 sikap petugas CS terhadap penanganan limbah medis sebagian besar sudah baik yaitu sebesar $88 \%$, responden yang memiliki sikap cukup sebesar 6,7 \% sedangkan responden dengan sikap kurang baik sebesar 5,3 $\%$. Petugas dengan pengetahuan baik mempunyai respon positif terhadap penanganan limbah medis. Untuk petugas dengan sikap kurang baik dikarenakan mereka tidak setuju bahwa pemilahan limbah medis padat dari sumber penghasil limbah sehingga apabila menemukan sampah medis yang tercampur dengan sampah non medis akan dibiarkan saja tanpa dipisahkan terlebih dahulu. tempat sampah medis yang sudah dikosongkan tidak dilakukan pencucian pada prakteknya petugas hanya mengganti kantong plastiknya tentu saja hal ini bertentangan dengan ketentuan yang berlaku yang menyatakan bahwa tempat sampah 
medis harus dilakukan desinfeksi setelah dikosongkan dan pemilahan sampah harus dilakukan mulai dari sumbernya .Dengan tidak dilakukan pencucian, tempat sampah akan terkontaminasi dengan sampah yag sudah dibuang yang kemungkinan saja mengandung kuman/ virus berbahaya. Sebaiknya petugas CS yang menangani sampah mengetahui cara pengelolaan sampah yang benar dan resiko yang mereka hadapi ketika menangani sampah medis.

Sikap yang terbentuk tergantung pada pengetahuan seseorang, semakin tinggi pengetahuan seseorang terhadap sesuatu, semakin positif sikap yang terbentuk. Pembentukan sikap responden dalam mengumpul limbah medis sesuai dengan pengalaman pribadi di lapangan(Jasmawat dkk. 2012).

\section{Tindakan petugas}

Tabel 5

DISTRIBUSI FREKUENSI PETUGAS CS BERDASARKAN TINDAKAN TERHADAP PENANGANAN LIMBAH MEDIS DI RSUD DR. SOETOMO SURABAYA TAHUN 2016

\begin{tabular}{lllll}
\hline & No & Kriteria & Jumlah & Presentase(\%) \\
& & & 69 & \\
\hline 1 & Baik & 1 & 92,00 \\
\hline 2 & Cukup & 5 & 1,33 \\
\hline 3 & Kurang & Jumlah & 75 & 6,67 \\
\hline & & & 100 \\
\hline
\end{tabular}

Berdasarkan hasil observasi mengenai tindakan Petugas CS di RSUD Dr. Soetomo Surabaya dalam penanganan limbah medis sebagian besar sudah baik yaitu $92 \%$, namun ada juga yang tindakanya kurang baik sebesar 6,7 \% dan $1,3 \%$ tindakanya cukup baik. Sebagian bear petugas dengan pengetahuan baik juga diikuti dengan tindakan yang baik walaupun masih ada petugas yang tindakanya tidak sesuai dengan ketentuan seperti petugas tidak segera mengangkut sampah setelah $2 / 3$ bagian terisi penuh dan masih ditemukan yang tidak menggunakan APD secara lengkap. Masih ditemukan timbunan sampah yang melebihi kapasitasnya. Penggunaan APD secara lengkap saat menangani sampah masih dianggap remeh oleh sebagian petugas, kurangnya kesadaran dari diri sendiri karena memakai masker dan sarung tangan dirasa mengganggu. Ada faktor dari ketersediaan fasilitas juga berpengaruh karena kehabisan stok APD diruangan dan harus menunggu pengawas CS untuk mengambilkan di gudang sedangkan mereka harus segera mengangkut sampah. Hal ini selaras dengan peneitian yang dilakukan oleh Purwoutomo (2004) yang menyatakan bahwa ada hubungan antara ketersediaan fasilitas dengan praktek pengumpul sampah medis di RSD Raden Soejati. Untuk mengatasi hal tersebut sebaiknya pihak ketiga memberi teguran kepada petugas yang bekerja tidak sesuai dengan aturan.

Suatu sikap belum otomatis terwujud dalam suatu tindakan. Untuk terwujudnya sikap agar menjadi suatu perbuatan nyata diperlukan faktor pendukung atau suatu kondisi yang memungkinkan, antara lain adalah fasilitas. Tim kerja dari WHO menyatakan bahwa penyebab seseong berperilaku tertentu salah satunya adalah keberadaan sumber daya. Surnber daya di sini mencakup keberadaan fasilitas (Bagoes dkk, 2003).

\section{Penanganan Limbah Medis}

Dari hasil penilaian tentang penanganan limbah medis di RSUD Dr. Soetomo Surabaya sudah memenuhi syarat. Adapun rincian dari tiap tahapan sebagai berikut :

\section{Tahap pemilahan dan pewadahan}

Secara umum Pemilahan adalah proses pemisahan sampah dari sumbernya, dalam PERMENKES 1204/MENKES/SK/X/2004 menjelaskan bahwa pemilahan jenis sampah medis padat mulai dari sumber yang terdiri dari sampah infeksius, sampah patologi, sampah benda tajam, sampah farmasi, sampah sitotoksis, sampah kimiawi, sampah radioaktif, sampah kontainer bertekanan, dan sampah dengan kandungan logam berat. Sampah radioaktif menggunakan warna merah, sampah sangat infeksius menggunakan warna kuning, sampah infeksius, patologi dan anatomi menggunakan warna kuning, sampah sitotoksis menggunakan warna ungu, sampah kimia dan farmasi menggunakan warna cokelat. Manajemen pemilahan sampah dapat diartikan sebagai suatu proses kegiatan pengelolaan sampah sejak dari sumber daya efektif yang diawali dari pemilahan,pengumpulan, penampungan,

pengangkutan hingga pemusnahan melalui pengendalian pengelolaan organisasi yang berwawasan lingkungan, sehingga dapat mencapai tujuan atau sasaran yang telah ditetapkan (Andarnita Aulia, 2012).

Sudah dilakukan pemilahan jenis limbah mulai dari sumber, sudah disediakan bak sampah tersendiri untuk sampah medis, non medis maupun benda tajam. Sehingga dari sumbernya sudah dibuang sesuai dengan jenis limbahnya oleh petugas paramedis. Untuk benda tajam sudah disediakan box berwarna kuning dengan logo khusus sesuai dengan persyaratan wadah limbah benda tajam. Pemilahan yang sudah baik dikarenakan petugas sudah mendapatkan 
pengarahan tentang penanganan sampah. Pemilahan berpengaruh terhadap pengelolaansampah medis karena, semakin baik pemilahan maka semakin baik pengelolaan sampahnya(Andarnita Aulia, 2012).

\section{Pengangkutan sampah medis}

Pengumpulan sampah merupakan proses pengambilan sampah yang dimulai dari tempat pengumpulan sampah sementara atau langsung tempat pembuangan akhir. Dalam hal ini pengangkutan sampah di RSUD Dr. Soetomo Surabaya sudah sesuai dengan SOP. Pengangkutan sampah dilakukan 3 kali sehari oleh petugas pengangkut sampah. Petugas pengangkut sampah mengambil sampah dari tiap ruangan untuk dibawa ke TPS. Gerobak sampah yang digunakan untuk mengangkut sampah sudah memenuhi syarat yaitu terbuat dari bahan yang kuat, kedap air dan terdapat tutup. Dibedakan antara gerobak sampah medis dan non medis. Petugas yang mengangkutnya dibedakan antara sampah medis dan non medis sehingga dapat mencegah tercampurnya sampah. Namun belum dibedakan antara jalur makanan dengan jalur pengangkutan sampah yang ditakutkan akan terjadi kontaminasi silang. Dalam pengambilan sampah medis tajam, kontainer sampah medis tajam sekali pakai diangkut keseluruhan beserta isinya ke dalam troli sampah medis dan digantiakan kontainer sampah medis tajam sekali pakai baru/ kosong oleh petugas ruangan. Kantong limbah yang sudah terisi penuh ditempatkan yang aman untuk kemudian diangkut oleh petugas pengangkut sampah namun masih ditemukan beberapa petugas yang tidak menggunakan APD dikarenakan kurangnya kesadaran pentingnya penggunaan APD.

\section{Tempat penampungan sementara}

Sampah yang sudah terkumpul dari setiap ruangan kemudian pagi harinya diangkut oleh petugas CS. Sampah medis dilakukan pemusnahan menggunakan incenerator yang beroperasi setiap hari dan sampah umum yang akan dipilah kembali untuk dijadikan kompos atau dibuang ke TPA. Lokasi TPS untuk sampah medis maupun non medis ini terletak pada lokasi yang mudah dijangkau kendaraan pengangkut sampah sehingga sudah sesuai dengan ketentuan yang berlaku.

\section{Pemusnahan}

Limbah medis dimusanahkan menggunakan insenerator sesuai dengan peraturan KepMenkes No 1204 Tahun 2004 yang menyebutkan bahwa sebelum dibuang ke TPA limbah medis harus dilakukan pengolahan sesuai jenisnya. Troly yang berisi sampah medis langsung dibawa menuju incenerator, sedangkan untuk sampah medis botol infus kaca dipisahkan untuk dilakukan penggilingan. Sampah medis selain botol infsu kaca dimasukkan ke dalam incenerator dan dibakar. Dalam pelaksanaan pembakaran sampah medis jarum yang terdapat di dalam kontainer disposable, dilakukan beserta kontainer disposablenya. Pemusnahan sampah medis dilakukan di Incenerator dibakar dengan suhu tinggi. Drumdrum tempat abu pasca pembakaran tersebut selanjutnya diserahkan kepada pihak ke III hal ini dikarenakan abu pasca pembakaran digolongkan dalam limbah bahan berbahaya dan beracun dan hanya boleh dibuang ke TPA tipe 1 . Hal ini sudah sesuai dengan standart prosedur operasional yang berlaku di RSUD Dr. Soetomo Surabaya dan KepMenkes No 1204 tahun 2004.

Keuntungan menggunakan insinerator adalah dapat mengurangi volume sampah, dapat membakar beberapa jenis sampah termasuk sampah B3 (toksik menjadi non toksik, infeksius menjadi non infeksius), lahan yang dibutuhkan relatif tidak luas, pengop erasinnya tidak tergantung pada iklim, dan residu abu dapat digunakan untuk mengisi tanah yang rendah. Sedangkan kerugiannya adalah tidak semua jenis sampah dapat dimusnahkan terutama sampah dari logam dan botol, serta dapat menimbulkan pencemaran udara bila tidak dilengkapi dengan pollution control berupa cyclon (udara berputar) atau penghisap debu.( Andarnita Aulia, 2012)

\section{KESIMPULAN}

1. Tingkat pengetahuan petugas CS di RSUD Dr. Soetomo Surabaya tentang penanganan limbah medis dengan kriteria penilaian "Baik" sebesar 90,8\% dan "Cukup" sebesar 9,2\%.

2. Sikap Petugas CS di RSUD Dr. Soetomo Surabaya tentang penanganan limbah medis dengan kriteria "Baik" sebesar 88\%, "Cukup" sebesar $6,7 \%$ dan 'Kurang baik" sebesar $5,3 \%$.

3. Tindakan Petugas CS di RSUD Dr. Soetomo Surabaya terhadap penanganan limbah medis dengan kriteria penilaian "Baik" sebesar 92\%, "Cukup" sebesar 1,3\% dan "Kurang baik" sebesar 6,7 \%.

4. Penanganan limbah medis di RSUD Dr. Soetomo sudah memenuhi syarat sesuai dengan KepMenkes No 1204 Tahun 2004.

\section{SARAN}

1. Untuk pihak RSUD Dr. Soetomo Surabaya

a) Diadakan penyuluhan tentang pentingnya penggunaan APD dan bahaya limbah medis

b) Membedakan jalur pengangkutan makanan dan jalur pengangkutan sampah

2. Untuk pihak ketiga

a) Memberi teguran kepada petugas CS yang bekerja tidak sesuai SOP

b) Menyediakan APD yang cukup di masingmasing ruangan agar tidak sampai kehabisan stok. 


\section{DAFTAR PUSTAKA}

Agustinus dan Devy, 2013. Pengelolaa Limbah Rumah Sakit. Jakarta, Salemba Medika

Andarnita Aulia, 2012. Faktor- Faktor Yang Mempengaruhi Pengelolaan Sampah Medis Di Badan Layanan Umum Daerah RSUD dr. Zainoel Abidin Banda Aceh.http://www.ejournal.uui.ac.id/jurnal/Au lia Andarnita-thz jurnal aulia andarnita s1.pdf, Jurnal Kesehatan Masyarkat, 07 Agustus 2016

Asmadi, 2013. Pengelolaan Limbah Medis Rumah Sakit. Yogyakarta, Gosyen Publishing

Bagoes, dkk. (2003). Perilaku Petugas Kebersihan Rumah Sakit dalam Pengelolaan Sampah di RS. Nirmala Suri Sukoharjo. http://download.portalgaruda.org/article.php ?article $=4437 \&$ val $=426$. Jurnal Unismus, 07 Agustus 2016

Depkes RI, 1995. Pedoman Sanitasi Rumah Sakit di Indonesia. Jakarta, Direktorat Jenderal PPM \& PLP

Didik dan Prajoga, 2005. Metodologi Penelitan. Surabaya, Unit Penelitian dan Pengabdian Masyarakat Politeknik Kesehatan Surabaya

Fransisca, 2013. Studi Tentang Perilaku Petugas Paramedis Dan Cleaning Service Terhadap Pengelolaan Limbah Medis Padat DI RSUD Dr. Soetomo Surabaya.KTI : Politeknik Kesehatan Surabaya

Jasmawati, Syafar dan Nurhaedar. 2012. Hubungan Pengetahuan, Sikap, Dan Keterrsediaan Fasilitas Dengan Praktik Petugas Pengumpul
Limbah Medis Di RSUD Abdul Wahab

Sjahranie Samarinda. http://pasca.unhas.ac.id/jurnal/files/a7d7db9 97b1202c0d12999f345c777f7.pdf, FKM Universitas Hasanuddin ,07 Agustus 2016

KepMenkes RI Nomor 1204 Tahun 2004 tentang Persyaratan Kesehatan Lingkungan Rumah Sakit

Notoatmodjo, Soekidjo, 2003. Pendidikan dan Perilaku Kesehatan. Jakarta, Rineka Cipta

Notoatmodjo, Soekidjo, 2012. Metodologi Penelitian Kesehatan. Jakarta, Rineka Cipta

Notoatmodjo, Soekidjo, 2012. Promosi Kesehatan dan Perilaku Kesehatan. Jakarta, Rineka Cipta

Purwoutomo, (2004). Hubungan Tingkat Pengetahuan dan Ketersediaan Fasilitas Pembuangan Sampah Medis dengan Praktek Petugas Pengumpul Sampah Medis di RSD. Raden Soejati Purwodadi. Jurnal Kesehatan Lingkungan,

Riduwan, 2005. Belajar Mudah Penelitian Untuk Guru, Karyawan dan Peneliti Pemula. Bandung, Alfabeta

Riduwan, 2010. Metode dan Teknik Menyusun Tesis. Bandung, Alfabeta

Sudiharti dan Solikhah, 2011. Hubungan Pengetahuan Dan Sikap Dengan Perilaku Perawat Dalam Pembuangan Sampah Medis Di Rumah Sakit PKU Muhamadiyah Yogyakarta. Jurnal Kesehatan Masyarakat

Sugiyono, 2014. Metode Penelitian Kuantitatif Kualitatif dan R\&D. Bandung, Alfabeta 